\title{
Analisis Kesulitan Siswa dalam Pembelajaran Matematika Menggunakan Learning Management System Selama Pandemi
}

\author{
Witri Melfawani ${ }^{1}$, Yenita Roza ${ }^{2}$, Maimunah ${ }^{3}$ \\ 1, 2,3 Program Studi Magister Pendidikan Matematika, Fakultas Keguruan dan Ilmu Pendidikan, Universitas Riau \\ Kampus Bina Widya KM. 12,5, Simpang Baru, Kec. Tampan, Kota Pekanbaru \\ witri.melfawani2052@grad.unri.ac.id
}

\begin{abstract}
The pandemic facing the world was causing many changes. One of the changes that has occurred was that from face-to-face learning to distance learning. This distance learning requires teachers and students to start using an online integrated Learning Management System (LMS). The new learning atmosphere and had to make adjustment experienced several obstacles. Thus, the purpose of this study was to determine the difficulties felt by students during mathematics learning using LMS. This type of research is descriptive qualitative. Data collection techniques by distributing questionnaires via google form and interviews with several students. The research subjects used were SMPN 1 Gunung Sahilan. Based on the results of the study obtained some difficulties experienced by students during mathematics learning by using LMS, namely technical difficulties, adaptation difficulties, limitations of teaching materials and learning media. It can be concluded that learning mathematics using LMS during the pandemic still has many shortcomings.
\end{abstract}

Keywords: Learning Management System, Pandemic, Learning Mathematics

\begin{abstract}
Abstrak
Pandemi yang dihadapi oleh dunia menyebabkan banyak perubahan. Salah satu perubahan yang terjadi adalah pembelajaran yang dulunya tatap muka menjadi pembelajaran jarak jauh. Pembelajaran jarak jauh ini mengharuskan guru dan siswa mulai menggunakan Learning Management System (LMS) yang terintegrasi secara online. Suasana pembelajaran yang baru dan harus melakukan penyesuaian mengalami beberapa kendala. Dengan demikian tujuan dari penelitian ini adalah untuk mengetahui kesulitan yang dirasakan oleh siswa selama pembelajaran matematika menggunakan LMS. Jenis penelitian ini adalah deskriptif kualitatif. Teknik pengumpulan data dengan menyebarkan angket melalui google form dan wawancara dengan beberapa siswa. Subjek penelitian yang digunakan adalah siswa SMPN 1 Gunung Sahilan. Berdasarkan hasil penelitian didapatkan beberapa kesulitan yang dialami oleh siswa selama pembelajaran matematika dengan menggunakan LMS yaitu kesulitan teknis, kesulitan adaptasi, keterbatasan bahan ajar dan media pembelajaran. Dengan demikian dapat disimpulkan bahwa pembelajaran matematika menggunakan LMS selama pandemi masih memiliki banyak kekurangan.
\end{abstract}

Kata kunci: Learning Management System, Pandemi, Pembelajaran Matematika

Copyright (c) 2022 Witri Melfawani, Yenita Roza, Maimunah

Corresponding author: Yenita Roza

Email Address: yenita.roza@ @ecturer.unri.ac.id (Kampus Bina Widya KM. 12,5, Kota Pekanbaru)

Received 01 July 2022, Accepted 08 February 2022, Published 11 February 2022

\section{PENDAHULUAN}

Makhluk kecil tak kasatmata berhasil membuat gempar dunia selama lebih dari setahun, dijuluki dengan covid-19 yang telah memaksa dunia jungkir balik membuat perubahan agar kehidupan tetap berjalan. Perubahan dilakukan untuk mengurangi penyebaran virus covid-19 yaitu dengan social distancing. Salah satu perubahan yang dilakukan negara di dunia khususnya Indonesia untuk ranah pendidikan adalah Belajar Dari Rumah (BDR). BDR merupakan suatu model pembelajaran baru dalam dunia pendidikan yang mampu menjawab kelemahan utama tatap muka, yaitu mampu menanggulangi keterbatasan ruang dan waktu dengan memanfaatkan jaringan internet (Hasan, 2020). Pemerintah dan guru melakukan berbagai cara untuk mendukung keterlaksanaan program BDR. Pendidikan akan tercipta dengan baik apabila di suatu Negara mampu menerapkan 
kurikulum yang tepat sesuai dengan perkembangan zaman (Hoiriyah, 2019)

Guru memiliki cara untuk menunjang keterlaksanaan pembelajaran BDR yang melibatkan banyak sekali aplikasi atau lebih dikenal dengan Learning Management System (LMS). Pembelajaran yang melibatkan jaringan internet dasarnya adalah pembelajaran virtual yang dilaksanakan dengan aplikasi virtual yang ada (Syarifudin, 2020). Beberapa jenis LMS digunakan yaitu Google Classroom, Google Meet, WhatsApp, serta aplikasi lainnya. Pembelajaran jarak jauh terbagi menjadi dua jenis yaitu sinkron dan asinkron. Pembelajaran sinkron berupa kelas virtual yang dapat menghubungkan guru dan siswa secara langsung dan dapat terjadinya interaksi baik diskusi, tanya jawab atau lainnya. Asinkron mirip dengan pembelajaran siswa secara mandiri (Kurniasari et al., 2020)

Salah satu Kabupaten yang ada di Provinsi Riau yaitu Kabupaten Kampar juga bergerak cepat dalam mengambil keputusan agar proses pembelajaran tetap berjalan walau tidak datang ke sekolah. Kabupaten Kampar memutuskan, bahwa selama pandemi proses pembelajaran untuk SD dan SMP mulai dari bulan April 2020 menggunakan sistem Belajar Dari Rumah. Pelaksanaan. BDR tentu saja membutuhkan jaringan internet yang stabil. Kampar merupakan salah satu kabupaten terdekat dari Kota Pekanbaru yang merupakan Ibukota Riau, secara geografis ini tidak menjadi jaminan bahwa daerah Kampar memiliki jaringan internet yang baik untuk mendukung keterlaksanaan BDR yang dilaksanakan secara online. Kampar merupakan daerah yang cukup luas dengan masih banyaknya lahan yang menjadi kawasan perkebunan sawit dan karet. Salah satu sekolah yang berada dalam keadaan tersebut adalah SMPN 1 Gunung Sahilan. Sekolah ini terletak di desa yang secara geografis berada di tengah perkebunan sawit. Kebanyakan siswa bertempat tinggal sekitar sekolah dan banyak juga siswa yang tinggal di dalam perkebunan sawit. Hal ini dikarenakan orangtua kebanyakan bekerja pada perusahaan yang mengolah sawit. Keadaan seperti ini tentu saja menjadi tantangan tersendiri oleh siswa terutama ketersediaan jaringan internet.

Dengan proses belajar menggunakan sistem BDR maka seluruh mata pelajaran difasilitasi secara daring. Salah satunya adalah matematika. Menurut Wahyudin, matematika merupakan disiplin ilmu yang mempelajari tentang sistem-sistem abstrak yang terbentuk berdasarkan elemen-elemen abstrak dimana elemen-elemen tersebut tidak dapat digambarkan dalam alur atau pola konkrit (Annurwanda \& Friantini, 2019). Dengan memperhatikan karakteristik matematika tersebut maka sudah menjadi kewajiban guru untuk mencari jalan keluar agar dapat memfasilitasi siswa dalam proses pembelajaran agar tercapainya tujuan pembelajaran walau tidak tatap muka secara langsung.

Pada pembelajaran matematika guru memfasilitasi beberapa keterampilan siswa yaitu : pertama, menyelesaikan persoalan yang menyangkut dengan matematika, baik itu kehidupan seharihari, bidang studi lain maupun matematika itu sendiri. Kedua, siswa terampil dalam menggunakan matematika untuk menunjang mata pelajaran lain. Ketiga, siswa mampu membuat analisis, sintesa dan mengambil kesimpulan. Keempat, siswa mampu menggunakan alat ukur, alat hitung dan tabel (Silalahi \& Hartono, 2020). Banyak sekali keterampilan yang harus dicapai siswa dengan proses pembelajaran yang dengan keadaan terpaksa harus dijalankan secara daring. 
Berdasarkan paparan di atas terdapat beberapa penyesuaian yang harus dilakukan dalam rangka melaksanakan proses BDR. Dengan demikian peneliti merasa perlu untuk mengetahui apa saja yang dirasakan siswa terutama kesulitan yang dialami oleh siswa SMPN 1 Gunung Sahilan dalam proses pembelajaran matematika menggunakan LMS selama pandemi.

\section{METODE}

Penelitian ini merupakan penelitian deskriptif kualitatif untuk mengetahui kesulitan yang dihadapi siswa selama pembelajaran matematika menggunakan LMS disaat pandemi. Penelitian ini dilakukan saat pandemi. Subjek penelitian adalah siswa di salah satu sekolah di Kabupaten Kampar yaitu SMPN 1 Gunung Sahilan.

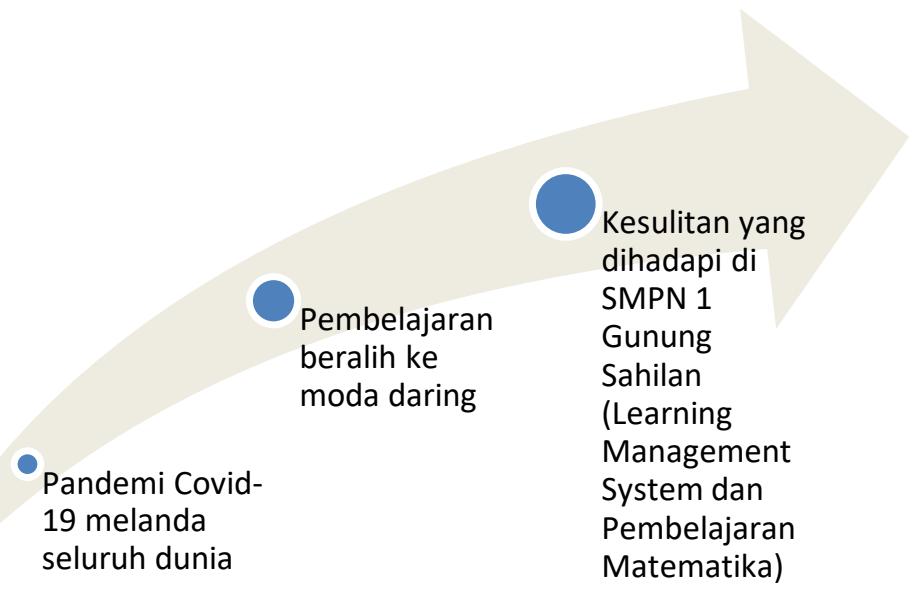

Gambar 1. Road Map penelitian

Data didapatkan dengan menggunakan instrumen berupa angket dengan cara menyebarkannya dan memanfaatkan Google Form yang dibagikan secara online ke siswa. Tidak hanya angket, data juga didukung dengan melakukan wawancara kepada beberapa siswa SMPN 1 Gunung Sahilan.

Berdasaran hasil angket melalui google form dan wawancara yang dilakukan pada beberapa siswa SMPN 1 Gunung Sahilan, mengenai kesulitan yang dihadapi saat proses pembelajaran matematika dengan menggunakan LMS ketika pandemi, terbagi menjadi tiga bagian. Tiga bagian merupakan hal yang sudah peneliti kerucutkan dan simpulkan karena sebagian besar siswa mengalami hal yang sama namun hanya redaksinya yang berbeda. Aplikasi yang digunakan sebagai LMS adalah WhatsApp, Google Classroom, dan Google Meet. Kesulitan pertama yang dihadapi oleh siswa merupakan hal mendasar, yaitu kesulitan terhadap teknis. Untuk kesulitan secara teknik terdapat di tabel 1. 
Tabel 1. Kesulitan Teknis

\begin{tabular}{|c|l|}
\hline No & \multicolumn{1}{|c|}{ Aspek } \\
\hline 1 & $\begin{array}{l}\text { Sinyal yang kurang mendukung, baik dengan } \\
\text { keadaan tidak ada sinyal atau sinyal yang lamban. }\end{array}$ \\
\hline 2 & Harga paket data yang mahal. \\
\hline 3 & $\begin{array}{l}\text { Kemampuan device yang digunakan, sangat terbatas } \\
\text { dalam hal ini memori internal. }\end{array}$ \\
\hline
\end{tabular}

Kesulitan kedua yaitu kesulitan dalam mengoperasikan LMS yang digunakan. Pada kesulitan ini saya mengelompokkan menjadi kesulitan dalam adaptasi. Kesulitan tersebut terdapat di tabel 2.

Tabel 2. Kesulitan Adaptasi

\begin{tabular}{|c|l|}
\hline No & \multicolumn{1}{|c|}{ Aspek } \\
\hline 1 & $\begin{array}{l}\text { Siswa tidak paham cara menggunakan Google } \\
\text { Classroom terutama saat mendownload materi dan } \\
\text { menyerahkan tugas. }\end{array}$ \\
\hline 2 & $\begin{array}{l}\text { Siswa kesulitan dalam menggunakan Google Meet } \\
\text { dalam melakukan pembelajaran sinkron. }\end{array}$ \\
\hline
\end{tabular}

Kesulitan ketiga berasal dari guru yaitu keterbatasan bahan ajar dan media pembelajaran yang digunakan guru dalam memfasilitasi siswa. Dalam hal ini banyak sekali pendapat siswa, salah satunya merasa kesulitan dalam memahami materi. Beberapa pendapat tersebut terdapat di tabel 3.

Tabel 3. Keterbatasan Bahan Ajar dan Media

\begin{tabular}{|c|l|}
\hline No. & \multicolumn{1}{|c|}{ Aspek } \\
\hline 1 & $\begin{array}{l}\text { Siswa merasa senang dengan adanya video yang } \\
\text { menunjang pemberian materi, tetapi lebih baik } \\
\text { dalam animasi. }\end{array}$ \\
\hline 2 & $\begin{array}{l}\text { Siswa merasa lebih paham jika guru memberikan } \\
\text { rangkuman materi beserta contoh soal dan } \\
\text { penyelesaiannya. }\end{array}$ \\
\hline 3 & $\begin{array}{l}\text { Siswa lebih suka berdiskusi melalui google meet } \\
\text { sehingga lebih paham dan interaksi dengan guru } \\
\text { lebih intens }\end{array}$ \\
\hline
\end{tabular}

Kesulitan pada kelompok ketiga ini yang menjadikan siswa belum memahami materi yang diajarkan. Siswa menganggap bahwa dengan pembelajaran dengan BDR ini tidak optimal. Jika melakukan diskusi melalui grup chat tidak dapat memfasilitasi siswa untuk mengungkapkan idenya dengan baik.

\section{HASIL DAN DISKUSI}

Berdasarkan hasil yang didapatkan melalui angket dan wawancara dengan beberapa siswa SMPN 1 Gunung Sahilan. Aplikasi yang digunakan sebagai LMS untuk menunjang pembelajaran matematika secara daring dapat dilihat di Gambar 2 


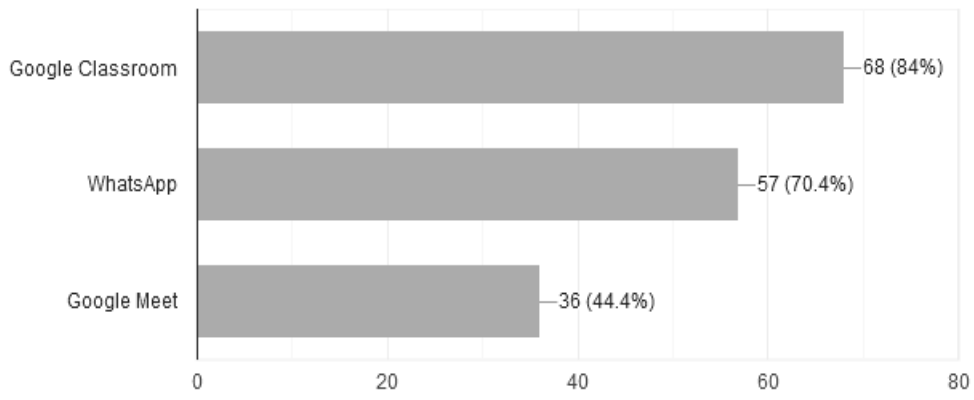

Gambar 2. Aplikasi yang digunakan sebagai LMS

Aplikasi google classroom menjadi pilihan utama yang banyak digunakan, hal ini karena aplikasi ini yang dapat digunakan dengan sangat fleksibel untuk proses pembelajaran terutama untuk memberikan materi dan menyerahkan tugas bagi siswa. Pada aplikasi ini guru dapat memberikan nilai dan komentar terhadap pekerjaan siswa. WhatsApp dijadikan pilihan utama dalam melakukan interaksi yang menggunakan tulisan atau sering disebut dengan chat. WhatsApp dijadikan salah satu LMS yang diminati karena aplikasi ini dapat bekerja pada sinyal yang lemah dan dapat menampung beberapa orang dalam suatu grup diskusi. Beberapa kelebihan WhatsApp adalah hemat kuota, materi dapat diakses siswa yang berada pada group belajar, dan bisa melakukan diskusi (Saragih \& Ansi, 2020). Google meet terkadang menjadi pilihan karena beberapa siswa merasa kurang terfasilitasi jika diskusi hanya melalui WhatsApp, namun masalah teknis menjadikan aplikasi ini tidak menjadi prioritas. Beberapa aplikasi yang prinsipnya seperti E-learning digunakan sebagai pembelajaran mandiri bagi siswa (Thi Thanh Hong, Thuy Giang, Nam Phuong, \& Quoc Khanh, 2018).

Ada 3 kesulitan secara garis besar yang dialami, yaitu: kesulitan teknis, kesulitan adaptasi, dan keterbatasan bahan ajar serta media yang digunakan. Kesulitan-kesulitan ini tentu saja menjadi kendala bagi guru maupun siswa dalam mencapai tujuan pembelajaran. Kesulitan teknis dan kesulitan adaptasi terdapat di Gambar 3 .

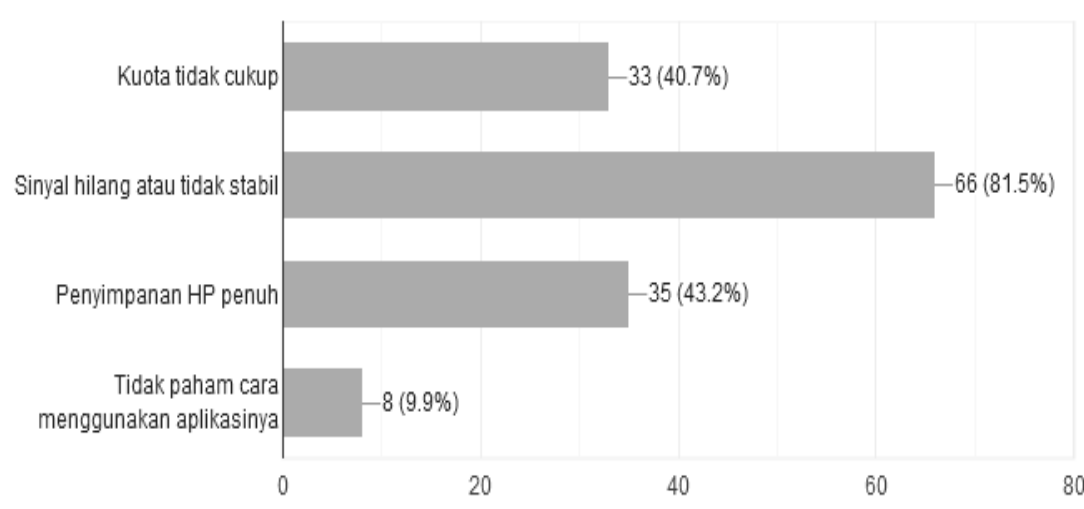

Gambar 3. Kesulitan teknis dan adaptasi yang dihadapi siswa

Kesulitan teknis ada beberapa faktor yang pertama adalah kesulitan dalam mendapatkan sinyal yang stabil. Seperti yang sudah diketahui bahwa SMPN 1 Gunung Sahilan berada di tengah perkebunan sawit. Keadaan yang seperti ini tentu saja wajar terjadi, sehingga siswa terkadang mencari 
tempat selain rumah agar mendapatkan sinyal yang stabil. Hal ini dilakukan agar siswa tetap dapat mengikuti pembelajaran matematika. Kemudian sulitnya sinyal yang stabil mengakibatkan siswa terkadang terlambat dan gagal dalam menyerahkan tugas yang sudah dibuat pada LMS yaitu google classroom. Tak hanya itu, kesulitan teknik ini juga mengakibatkan siswa tidak dapat mengunduh materi yang diberikan oleh guru. Guru diharapkan untuk dapat memilih dan meminimalisir untuk mengirim materi yang berkapasitas memori yang cukup besar (Mustakim, 2020).

Harga paket data yang mahal, keadaan ini mengakibatkan kuota yang diperlukan tidak mencukupi untuk pembelajaran daring. Ada beberapa siswa yang ingin mengundurkan diri karena tidak mampu menyediakan kuota untuk pembelajaran daring. Perlu untuk diketahui bahwa ekonomi dari orang tua siswa SMPN 1 Gunung Sahilan berasal dari keluarga menengah ke bawah. Jarak tempuh yang jauh dari kota menyebabkan harga barang menjadi lebih mahal termasuk paket data. Device yang digunakan memiliki keterbatasan seperti memori internal yang terbatas, menyebabkan siswa tidak dapat membuka atau mendownload bahan ajar yang telah diberikan oleh guru. Salah satu alternatif yang diberikan guru adalah pemanfaatan WhatsApp yang lebih intens, karena aplikasi ini dianggap lebih ringan. Sehingga guru lebih memfokuskan untuk berdiskusi, namun aplikasi chat group belum maksimal dalam mengaktifkan keterlibatan siswa dalam proses pembelajaran secara optimal. Pembelajaran online kurang terkontrol karena tidak langsung tatap muka (Herliandry, Nurhasanah, Suban, \& Heru, 2020)

Kesulitasn adaptasi, kesulitan ini tidak hanya dirasakan oleh siswa namun oleh guru juga demikian. Mengingat bahwa program BDR ini adalah salah satu langkah cepat yang diambil, untuk tetap melaksanakan proses pembelajaran di tengah pandemi. Keadaan ini mengharuskan guru dan siswa sama-sama belajar untuk memahami aplikasi yang dipakai sebagai LMS dalam rangka menjalankan BDR. Pembelajaran daring yang terkesan mendadak karena covid-19 ini menyebabkan persiapan yang tidak optimal. Sehingga menyebabkan siswa merasa tidak siap dalam pelaksanaannya (Fauzy \& Nurfauziah, 2021).

Kesulitan adaptasi berupa kesulitan siswa dalam memahami kerja aplikasi yang digunakan sebagai LMS, sebagai contoh melampirkan dan menyerahkan tugas melalui Google Classroom, hal ini adalah pengalaman pertama dalam melaksanakan proses belajar jarak jauh. Selain itu adalah kesulitan dalam mengoperasikan Google Meet. Banyak sekali siswa yang merasa kewalahan jika guru sudah menggunakan aplikasi ini. Salah satunya kewalahan dalam bergabung di ruang diskusi. Salah satu solusi yang dapat dilakukan adalah dengan meminta bantuan kepada orang tua, saudara atau orang terdekat dalam menggunakan aplikasi (Patimah, 2020). Kesulitan ketiga yaitu keterbatasan bahan ajar serta media yang digunakan. Berdasarkan hasil angket dan wawancara dengan siswa ada beberapa sumber belajar dan media yang digunakan guru dapat dilihat pada Gambar 4 berikut. 


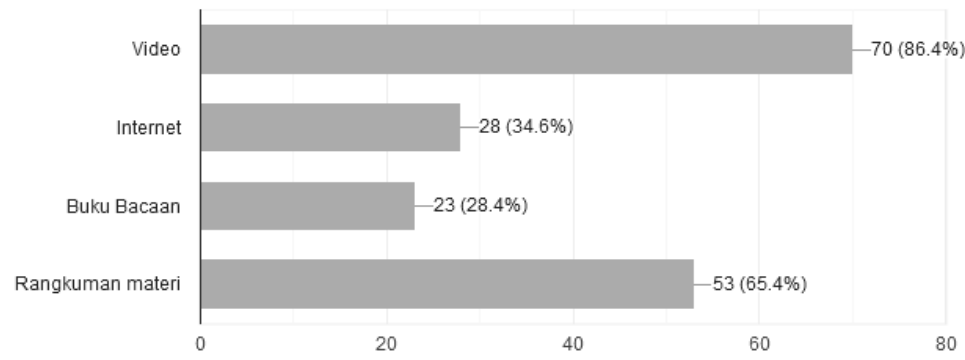

Gambar 4. Sumber belajar dan media yang digunakan guru

Pemilihan dan penggunaan sumber belajar dan media pembelajaran oleh guru sudah cukup variatif. Hal ini terlihat dari Gambar 4 bahwa penggunaan sumber belajar dan media yang sering berupa video pembelajaran, kemudian rangkuman materi, internet, dan buku bacaan. Berikut salah satu contoh dari LMS guru dalam pembelajaran matematika pada Gambar 5 .

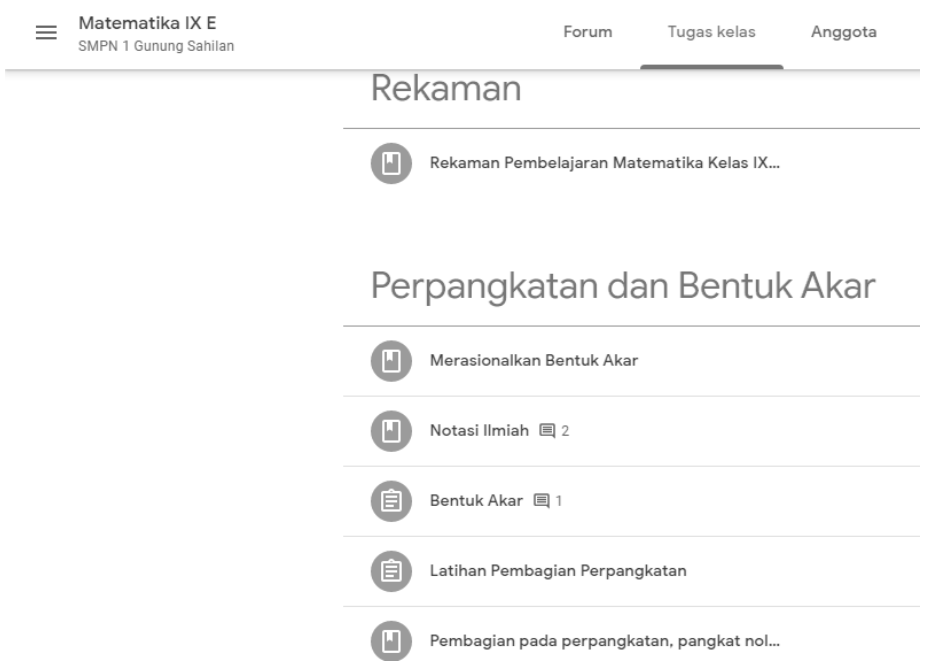

Gambar 5. Salah satu tampilan LMS guru

Berdasarkan Gambar 5, dapat kita amati bahwa tampilan pada LMS sudah dibagi dalam beberapa kelompok berdasarkan materi, terlihat bahwa guru memberikan video pembelajaran, memberika link tentang materi,membuatkan rangkuman serta melakukan diskusi dengan menyematkan hasil rekaman Google Meet sehingga dapat diakses siswa ketika dibutuhkan.

Berdasarkan wawancara dengan siswa bahwa guru akan memfasilitasi pembelajaran dengan video. Video yang berupa tutorial yang dibuat oleh guru yang bersangkutan. Video terdiri penjelasan materi serta beberapa contoh dalam menyelesaikan permasalahan yang berkaitan dengan materi yang diberikan. Namun, beberapa siswa menganggap video yang diberikan belum maksimal. Siswa mengatakan akan lebih baik jika video pembelajaran yang diberikan memuat animasi yang menarik, sehingga siswa lebih bersemangat dalam belajar.

Internet merupakan hal pokok dalam BDR karena harus mengandalkan beberapa informasi yang berasal dari beberapa laman pembelajaran. Guru sudah memberikan link yang dianggap dapat 
menunjang pembelajaran. Namun, beberapa siswa masih merasa kewalahan dalam mencari sumber informasi lainnya melalui internet. Hal ini tentu saja mengakibatkan siswa tidak kreatif dalam proses pembelajaran. Buku bacaan dijadikan pedoman awal untuk siswa mempelajari suatu materi. Jika dirasa ada yang tidak dimengerti siswa dapat menanyakan kepada guru melalui forum diskusi.

Rangkuman materi, guru memfasilitasi dengan memberikan rangkuman materi beserta contoh soal dan penyelesaiannya yang dibuat sendiri oleh guru. Kendala dalam hal ini adalah beberapa siswa tidak paham dengan apa yang tertulis. Sehingga guru harus menjelaskan kembali melalui grup diskusi. Hal ini tentu saja mengurangi nilai guru sebagai fasilitator yang tidak dapat berinteraksi dengan maksimal antara narasumber dan pembelajaran (Mandasari, Rahmadhani, \& Wahyuni, 2020). Tak jarang guru membuat video tutorial kembali jika ada pertanyaan dari rangkuman materi dan dibagikan langsung melalui grup diskusi. Berdasarkan paparan tersebut dapat dilihat bahwa sumber belajar dan media yang dipilih memiliki kelemahan masing-masing jika digunakan dalam BDR menggunakan LMS. Sehingga siswa beranggapan bahwa pelayanan yang diberikan oleh guru kurang maksimal (Hutauruk \& Sidabutar, 2020).

Berikut beberapa cara yang dilakukan guru untuk memfasilitasi siswa dalam proses pembelajaran matematika menggunakan LMS dapat dilihat pada Gambar 6.

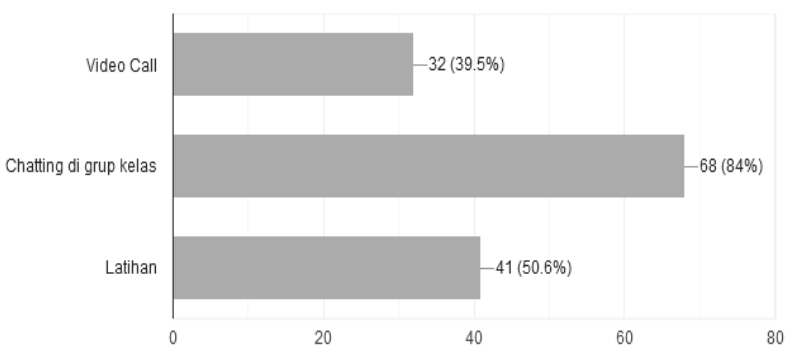

Gambar 6. Cara memfasilitasi siswa dalam pembelajaran matematika menggunakan LMS

Kegiatan yang paling banyak dilakukan untuk memfasilitasi siswa dalam proses pembelajaran matematika menggunakan LMS adalah diskusi melalui group chat. Diskusi pada group chat dapat menghubungkan guru dan siswa, namun untuk kegiatan ini siswa belum maksimal untuk terlibat dalam diskusi. Kemudian adalah pemberian latihan, guru memberikan latihan yang harus diserahkan setelah proses pembelajaran. Pemberian latihan agar siswa dapat berlatih sendiri mengenai materi yang diajarkan.

Kegiatan selanjutnya adalah videocall melalui goooge meet .Kegiatan ini lumayan menarik minat siswa, karena dalam proses pembelajaran siswa dapat langsung berdiskusi baik dengan guru maupun siswa lainnya. Beberapa siswa tidak dapat terfasilitasi karena kendala internet. Jika melakukan videocall harus menggunakan sinyal internet yang stabil. Jaringan internet merupakan 
faktor penting bagi lingkungan pembelajaran daring, tanpa adanya jaringan internet yang baik maka pembelajaran daring yang dilaksanaan tidak bisa berjalan maksimal (Handayani, 2020)

Berdasarkan hasil angket yang diisi oleh siswa, mengenai lebih memilih pembelajaran matematika dengan cara tatap muka, daring, atau hybrid dapat dilihat pada Gambar 7 berikut.

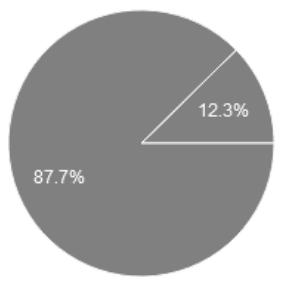

Gambar 7. Persentase cara belajar matematika yang disenangi siswa

Berdasarkan Gambar 5 sebesar 87,7\% siswa memilih pembelajaran matematika dengan tatap muka. Beberapa alasan dikemukakan oleh siswa yaitu dengan tatap muka siswa lebih muka memahami materi karena ketika tatap muka guru dapat memberikan beberapa selingan dengan canda tawa sehingga siswa tidak terlalu tegang selama proses pembelajaran. Alasan yang paling banyak adalah jika dengan tatap muka siswa dapat berinteraksi dengan guru secara langsung jika tidak memahami suatu materi. Senada dengan Hartono, 2017 menyatakan bahwa sistem pembelajaran daring mengurangi interaksi sosial antara pendidik dan peserta didik yang berakibat pada kurangnya kontrol akademik dan sosial.(Setiawan \& Aden, 2020)

Sisanya 12,3\% memilih hybrid learning. Alasan yang dikemukakan oleh siswa beragam ada yang menyatakan bahwa dengan pembelajaran seperti itu ia dapat membantu pekerjaan orang tuanya. Selain itu selama proses pembelajaran dari rumah orang tua lebih intensif dalam mendampingi anak belajar. Kerjasama antara guru, orang tua , serta pihak lainnya sangat diperlukan dalam pendidikan terutama saat pandemi, pengawasan dan pendampingan dari orang tua sangat dibituhkan (Dewi, 2020). Alasan terakhir adalah dengan sistem pembelajaran hybrid learning dapat memaksimalkan ketika berinteraksi dengan guru dan mencari informasi tambahan dengan memanfaatan internet.

Dengan keadaan yang mengharuskan pembelajaran berlangsung dari rumah secara online menggunaan LMS membuat matematika menjadi mata pelajaran yang dianggap semakin sulit. Senada dengan penelitian yang dilakukan oleh Fauzy dan Nurfauziah, 2021 menyatakan bahwa kenyataannya matematik masih ada siswa yang kurang meminati matematika terutama saat pembelajaran daring (Fauzy \& Nurfauziah, 2021).

Kesulitan-kesulitan yang dirasakan oleh siswa selama proses pembelajaran matematika menggunakan LMS selama pandemi tentu saja menjadi kendala bagi siswa untuk memahami materi. Pemahaman yang kurang tentu saja akan mengakibatkan proses pembelajaran menjadi tidak maksimal dan berdampak pada hasil belajar yang didapatkan siswa juga tidak maksimal. Dengan demikian diperlukan persiapan yang matang untuk menghadapi cara pembelajaran secara daring baik dari segi teknis yang termasuk sinyal, kuota serta daya penyimpanan suatu perangkat. Kemampuan manusia itu 
sendiri dalam mengoperasikan aplikasi yang akan digunakan, serta pemilihan sumber belajar dan media pembelajaran yang lebih inovatif. Guru hendaknya menambah pengetahuan dalam perkembangan strategi yang cocok dan dapat digunakan dalam keadaan daring (Annur, 2020). Solusi dari kesulitan pembelajaran matematika e-learning (daring) adalah dengan menerapkan pembelajaran e-learning yang menarik, efektif dan menyenangkan. Selanjutnya ialah dengan memaksimalkan ketersediaan fasilitas teknologi yang sudah ada, sehingga pembelajaran daring dapat berjalan sesuai dengan yang direncanakan (Utami \& Cahyono, 2020). Selain itu kurikulum yang flesibel sangat dibutuhkan dalam keadaan seperti ini (Wahyono, Husamah, \& Budi, 2020). Hal ini sudah dibuktikan oleh pemerintah dengan mengeluarkan kurikulum darurat covid-19 yang memberikan kebebasan kepada guru yang bersangkutan dalam menjalankan pembelajaran.

\section{KESIMPULAN}

Berdasarkan paparan di atas dapat disimpulkan bahwa ada 3 kelompok besar kesulitan yang dihadapi siswa selama proses pembelajaran matematika menggunakan LMS selama pandemi, yaitu: kesulitan teknis, yang terdiri dari sulitnya mendapatkan jaringan internet yang stabil, mahalnya kuota sehingga tidak mencukupi untuk mengikuti proses pembelajaran, dan keterbatasan perangkat yang digunakan dalam hal penyimpanan. Kesulitan adaptasi, berupa masih kurang paham terhadap aplikasi yang digunakan dalam menunjang pembelajaran matematika menggunakan LMS. Terakhir, keterbatasan bahan ajar serta media yang digunakan oleh guru sehingga hanya beberapa siswa yang terfasilitasi.

\section{REFERENSI}

Annur, M. F. (2020). Analisis Kesulitan Mahasiswa Pendidikan Matematika Dalam Pembelajaran Daring Pada Masa Pandemi Covid-19. Jurnal Kajian, Pnelitian Dan Pengembangan Kependidikan, 11, 195-201.

Dewi, W. A. F. (2020). Dampak COVID-19 terhadap Implementasi Pembelajaran Daring di Sekolah Dasar. Edukatif: Jurnal Ilmu Pendidikan, 2(1), 55-61. https://doi.org/10.31004/edukatif.v2i1.89 Fauzy, A., \& Nurfauziah, P. (2021). Kesulitan Pembelajaran Daring Matematika Pada Masa Pandemi COVID-19 di SMP Muslimin Cililin. Jurnal Cendekia : Jurnal Pendidikan Matematika, 5(1), 551-561. https://doi.org/10.31004/cendekia.v5i1.514

Handayani, L. (2020). Keuntungan , Kendala dan Solusi Pembelajaran Online Selama Pandemi Covid-19: Studi Ekploratif di SMPN 3 Bae Kudus Lina Handayani. Journal Industrial Engineering \& Management Research, 1(2), 16.

Herliandry, L. D., Nurhasanah, Suban, M. E., \& Heru, K. (2020). Transformasi Media Pembelajaran Pada Masa Pandemi Covid-19. Jurnal Teknologi Pendidikan, 22(1), 65-70.

Hutauruk, A., \& Sidabutar, R. (2020). Kendala pembelajaran daring selama masa pandemi di kalangan mahasiswa pendidikan matematika: Kajian kualiatatif deskriptif. Journal of 
Mathematics Education and Applied, 02(01), 45-51.

Mandasari, L., Rahmadhani, E., \& Wahyuni, S. (2020). Efektivitas Perkuliahan Daring Pada Mata Kuliah Analisis Kompleks Selama Pandemi Covid 19. Jurnal As-Salam, 4(2), 269-283. https://doi.org/10.37249/as-salam.v4i2.205

Mustakim, M. (2020). Efektivitas Pembelajaran Daring Menggunakan Media Online Selama Pandemi Covid-19 Pada Mata Pelajaran Matematika. Al Asma: Journal of Islamic Education, 2(1), 1. https://doi.org/10.24252/asma.v2i1.13646

Patimah, S. (2020). ... Aktivitas Pembelajaran Matematika Pada Materi Pecahan Campuran Berbasis Daring (Melalui Aplikasi Whatsapp) Di Masa Pandemi .... JKPD (Jurnal Kajian Pendidikan Dasar), 5.

Saragih, E. M., \& Ansi, R. Y. (2020). Efektivitas Penggunaan Whatsapp Group Selama Pandemi Covid-19 Bagi Pelaku Pendidik. Prosiding Seminar Nasional Multidisiplin Ilmu Universitas Asahan, (September), 207-212.

Setiawan, T. H., \& Aden. (2020). Efektifitas Penerapan Blended Learning Dalam Upaya Meningkatkan Kemampuan Akademik Mahasiswa Melalui Jejaring Schoology Di Masa Pandemi Covid-19. Jurnal Pembelajaran Matematika Inovatif (JPMI), 3(5), 493-506. https://doi.org/10.22460/jpmi.v3i5.493-506

Thi Thanh Hong, N., Thuy Giang, T., Nam Phuong, N., \& Quoc Khanh, M. (2018). The Status of Applying E-learning in Holding Students' Self-Study of the Subject Education in Pedagogical Universities in Vietnam. American Journal of Educational Research, 6(6), 804-810. https://doi.org/10.12691/education-6-6-32

Utami, Y. P., \& Cahyono, D. A. D. (2020). Study At Home: Analisis Kesulitan Belajar Matematika Pada Proses Pembelajaran Daring. Jurnal Ilmiah Matematika Realistik, 1(1), 20-26. https://doi.org/10.33365/ji-mr.v1i1.252

Wahyono, P., Husamah, H., \& Budi, A. S. (2020). Guru profesional di masa pandemi COVID-19: Review implementasi, tantangan, dan solusi pembelajaran daring. Jurnal Pendidikan Profesi Guru, 1(1), 51-65. 